DOI: 10.17707/AgricultForest.62.2.05

\author{
Mykola M.KHARYTONOV, \\ Valentina T.PASHOVA, Maria O.BAGORKA, \\ Vladimir I. KOZECHKO,Tamara O.DUDAR ${ }^{1}$
}

\title{
ARABLE LANDS DEGRADATION \\ IN THE NORTHERN STEPPE ZONE OF UKRAINE
}

\begin{abstract}
SUMMARY
The case study is devoted to the agroecological peculiarities of the eroded soils fertility taking into account their genesis and morphology. The researched soils are located on the slopes of different exposure in the subzone of ordinary black mollisols. The laboratory and field observation of the eroded soils was carried out on the base of training farm "Samarsky". The research of quantitative and qualitative composition of physical and chemical qualities in arable soils on the slopes and watersheds was performed. On the basis of it the dependence between the eroded soils fertility and environmental conditions was established. On their genesis, the slope soils are represented by the variety of watershed types of black mollisols. These soils are considered as special more arid soils additionally superimposed with erosion process. They represent genetic forms of intrazonal and zonal types. The humus content in the $0-30 \mathrm{~cm}$ layer in the plain amounted to $4.1 \%$, while decreasing on the northern exposure slope by one third, and on the southern exposure slope - twice. The qualitative humus change was observed: the humic acid content decrease when insignificant change of fulvic acids.
\end{abstract}

Keywords: degradation, soil, slope, genesis, fertility, humus

\section{INTRODUCTION}

As it is known, a significant part (8\%) of the mollisoils world reserves is concentrated in Ukraine. The share of these lands in Ukraine is about $36 \%$ [Anisimova et al., 2009]. There is a growing need for crop production and animal husbandry to ensure preservation of fertility for the plain and slope lands. The black soils degradation processes development in Ukrainian Steppe was fixed from the end of the 19 century [Dokuchaev,1983; Kovda, 1989]. It was shown that rain and melt water have an impact on the soil physical properties. As a result of soil loss the first thing to lose is the silt fraction, soils most valuable part. It was mentioned the fight against erosion is of high priority taking into account the risk of drought. That is why special attention has to be given to the winter soil moisture conservation, the study of washout and leaching processes.

\footnotetext{
${ }^{1}$ Mykola M.Kharytonov, (corresponding author: nick-nick@mail.ru), Valentina T.Pashova, Maria O.Bagorka, Vladimir I. Kozechko, Dnipropetrovsk State Agrarian and Economic University, UKRAINA, Tamara O.Dudar, National Aviation University, Kiev, UKRAINA.

Notes: The authors declare that they have no conflicts of interest. Authorship Form signed online.
} 
The black soils are known to be spread in several countries of the world. Most of the world's mollisols occur in three regions of the northern hemisphere and one region - the south of the equator, the Parana-La Plata basin of South America. Mollisols are known in other soil classification systems as Chernozems, Kastanozems and Phaeozems and Isohumosols or Black soils (Artigas,2010; Liu $\mathrm{X}$ et al.2012). On a world-wide basis, soil scientists generally speak of four main major regions of Mollisols . One is located in the central North America radiating across the central plains of the United States and the southern Canada. The next two regions appear as a discontinuous belt which extends across the southeastern Europe and the central Asia (Liu X et al., 2012). The western belt begins in the sub-humid steppes of the south-central Europe and extends across Russia and into the eastern belt, which is best represented in the Northeast China (Kravchenko, 2009). Mollisols distribution strongly correlates with subboreal geographic belt, humid, semi-humid, and semi-arid zones, forest-steppe and steppe ecosystems, loess sediments. However, their spread is not limited to those areas. The Ukrainian and the Chinese black soils keep together $16.8 \%$ of the World Mollisols and play the global role in the food security of both countries and the European-Asian continents in whole. It was established that some territories occupied by black soil in Ukraine and China have common features and problems (Kravchenko, 2009).

The factors affecting the erosion processes development can be divided into two groups: natural and anthropogenic. Natural factors include topography, geological conditions, climate, vegetation and physico-chemical properties of the soil (Spalevic et al., 2012; Spalevic et al., 2015). Rainfall and topography are the natural (abiotic) factors that determine the possibility of flow formation - the direct causes of erosion.

Climatic conditions, in many cases, provoke the erosion processes development. Precipitation has direct impact on the erosion process development. Such climatic factors as temperature, humidity, and winds have an indirect influence. Their indirect impact may occur in soil moisture level and may affect the conditions of runoff formation and erosion manifestation.

The spread of erosive processes are considerably influenced by rugged landscape. The morphological parameters of the relief, which determine the intensity of erosion processes are the depth of local bases of erosion, dismemberment of the territory of the gully network, the size of the watershed, the slope's length and exposure.

The intensity of soil loss increases with the growth of the length, steepness of slopes, and changes in exposure. The slopes of the opposite exposures vary greatly in the amount of incoming solar radiation, water runoff and soil loss, temperature, water and nutrient regimes of soil. This eventually affects the soil fertility and crop yields (Kharytonov et al, 2004) than the northern ones. Erosion losses of humus in the soils of the southern slopes reach $60 \%$, and in the northern - only $10-20 \%$ of total losses. 
In our research we set the following goals: a) to study the genesis of the eroded soil and changes of morphological characters under the abiotic factors impact; b) to see differences in the formation of soil profile genetic horizons fertility in plain and slopes of the northern and the southern exposure.

\section{MATERIAL AND METHODS}

Field observations were carried out at the ecological field station of the training farm located in the Dnipropetrovsk oblast in the northern part of the steppe zone of Ukraine (Kravchenko, 2010). Soil for controlled experiments and laboratory analysis was sampled from the same location. The farm coordinates are: $48^{\circ} 30^{\prime} \mathrm{N}$ lat. and $35^{\circ} 15^{\prime} \mathrm{E}$ long. The field station was used for many years as an area for intensive agricultural production and research (Kharytonov et.al.,2004 Kharytonov et.al,2009). It is located far away from the city of Dnipropetrovsk $(25-30 \mathrm{~km})$ enough to avoid industrial pollution effect (Anisimova et al., 2009).The research field occupies an area of 14 hectares and it is crossed by three ravines. One of them is of $30 \mathrm{~m}$ depth with a slope of $>7^{\circ}$, the other two have the slopes up to $3^{\circ}$ Comparison of the received information regarding the crop yield with the landscape features offers the possibility to differentiate the agricultural resource potential of the area. Studies were performed on plain (full-height normal soil), on the northern exposition slope (low eroded soil), the slope of the southern exposure (middle level of erosion). Special attention was paid to the one of the three ravines: flat terrain, slopes of the southern and the northern exposure. Thus, the experiments reported here compare soils from three types of landscapes: level soils (0-1\% slope) with no observable erosion (E0), mildly sloped soils (1-3\%) with mild erosion (E1, 0-10 $\mathrm{cm}$ topsoil loss), and moderately sloped soils (5-7\%) with moderate erosion (E2, up to $30 \mathrm{~cm}$ topsoil loss). Coincidentally, in the study area, the mildly sloped soils have the northern exposure, and the moderately sloped soils have the southern exposure. The soil type in the experimental area is referred to the central steppe chernozem in the FSU (former Soviet Union) system (Kravchenko, 2010). In keeping with the lower productivity status of the eroded soils, fertilizer was not applied, but the two years of alfalfa just before wheat promoted reasonable growth. Numerous soil characteristics were determined for each erosion severity and each $10 \mathrm{~cm}$ depth increment from bulk samples. Generally, duplicate determinations were made and averaged. The depth increments were assigned to general soil horizons, according to the Russian soil taxonomy system (Dokuchaev, 1883, Kovda, 1989, Kravchenko,2012). These are defined as follows (with correspondence to the Ukrainian soil taxonomy system noted in parentheses:

A $(\mathrm{H})$ - upper horizon with very prominent humus accumulation

$\mathrm{B}_{1}(\mathrm{Hp})$ - upper transition horizon, with considerable humus

$\mathrm{B}_{2}(\mathrm{Ph})$ - lower transition horizon, with little humus

$\mathrm{C}(\mathrm{P})$ - underlying parent material 
The A, B1, B2 and C horizons encompassed depths of 0-40, 40-60, 60-80 and 80-100 $\mathrm{cm}$ for E0; depths of 0-30, 30-50, 50-70, and 70-100 $\mathrm{cm}$ for E1, and depths of $0-30,30-50$, and $50-100 \mathrm{~cm}$ for $\mathrm{E} 2$ (with the A horizon absent entirely due to erosion).

Soil samples were taken every $10 \mathrm{~cm}$ to a depth of $100 \mathrm{~cm}$. Up to 100 soil samples were taken in topsoil of ecological field Statistic assessment of eroded soils indexes spatial distribution in ploughed topsoil was made.Particle size determinations were made as follows. First, $1 \mathrm{~g}$ of soil was treated with room temperature $\mathrm{HCl}$, which dissolves most carbonates, although a small amount is left bound to cell particles. Upon drying, the dissolved carbonates escape as $\mathrm{CO}_{2}$, and the loss of weight is recorded. The remaining soil is mixed thoroughly with 1 liter of water and allowed to precipitate. At designated time intervals, aliquots were removed and per cent of specific particle sizes was estimated based on sedimentation of progressively smaller particles. Fractions determined were (diameter in $\mathrm{mm}$ in parentheses): medium to coarse sand (0.25-1), very fine to fine sand $(0.05-0.25)$, coarse silt $(0.01-0.05)$, fine silt $(0.005-0.01)$, silt/clay $(0.001-0.005)$ and clay $(<0.001)$. Values for fractions were summed to correspond with USDA definitions of sand ( $>0.05)$, silt ( $0.002-0.05)$ and clay $(<0.002)$. Since the silt/clay fraction as measured $(0.001-0.005)$ spanned the USDA definition, half of the silt/clay fraction was considered silt and half considered clay, since clay particles smaller than 0.001 were more prevalent than particles of fine silt. Allocating one-half of the silt/clay fraction to each had little influence on the overall proportion of clay vs. silt, since the fraction in question averaged $6 \%$ of the total soil weight, and was in no case greater than $10 \%$. Physical clay (clay(FSU)) is a standard definition in the Former Soviet Union (Dokuchaev Soil Institute, 1965), and is the summation of particle sizes less than $0.01 \mathrm{~mm}$ diameter (clay and fine silt by USDA classification), plus the per cent lost by $\mathrm{HCl}$ pre-treatment, which presumably was fine-particle carbonates. Clay(FSU) is reported here in addition to the USDA categories in order to facilitate comparison of our results with other FSU results (Kharytonov et al., 2004).

Carbonates were determined from the loss of mass that occurred as a result of $\mathrm{HCl}$ treatment. A sample of $1 \mathrm{~g}$ of finely ground soil was mixed with 40 $\mathrm{ml}$ of hot $0.1 \mathrm{~N} \mathrm{HCl} \mathrm{d}$ weighed after drying. The loss of mass was expressed as a percentage of the initial $1 \mathrm{~g}$ used. A $\mathrm{pH}$ meter was used to determine $\mathrm{pH}$ after placing $20 \mathrm{~g}$ of soil in $50 \mathrm{ml}$ of water $\left(\mathrm{pH}\left(\mathrm{H}_{2} \mathrm{O}\right)\right.$ or $50 \mathrm{ml}$ of $1 \mathrm{~N} \mathrm{KCl}$ aqueous solution $(\mathrm{pH}(\mathrm{KCl})$ and mixing thoroughly. Humus concentration was determined by placing $0.1 \mathrm{~g}$ of soil in $10 \mathrm{ml}$ of $0.4 \mathrm{~N} \mathrm{~K}_{2} \mathrm{Cr}_{2} \mathrm{O}$ aqueous solution, followed by titration with salt of Moore $\left(\mathrm{FeSO}_{4}\left(\mathrm{NH}_{4}\right)_{2} \mathrm{SO}_{4}\right)$. Humic acid and fulvic acid were determined by extraction followed by titration.

\section{RESULTS AND DISCUSSION}

Soil erosion is considered as a result of a complex interaction of natural and agricultural factors. Among the main ones are the natural terrain, erosion 
resistance, vegetation soil-protective role, climatic and meteorological conditions that determine the rainfall, nature of soil freezing, the size and intensity of surface runoff snowmelt and rainwater. An intensity of erosion processes depends on the slopes characteristics, their steepness, shape, length, exposure. These factors different combinations give specificity of soil profile forming in slopes, generally similar, but not identical with soils of the neighboring northward and southward latitudes.

The slopes' soil is a special, more arid soil which is under additional erosion impact. On the one hand eroded soils are formed under very specific conditions, on the other hand zonal conditions are also involved in the process of soil formation. That is why we consider the eroded soil as a separate genetic group of soil zone where they were formed. The main soil genetic group of the steppe are ordinary low humus content loess and loamy like loam. In the Dnipropetrovsk oblast their area is 1 million 280 thousand hectares (Anisimova et al, 2009).

The soil erosion severity, the steepness and aspect of slope greatly affect the soils physical properties. The intensity of many processes of the soil profile formation greatly depends on the soil texture. The silt and clay fractions profile distribution in arable soils of the plain, the slopes of the northern and the southern exposure are shown in the figure 1.

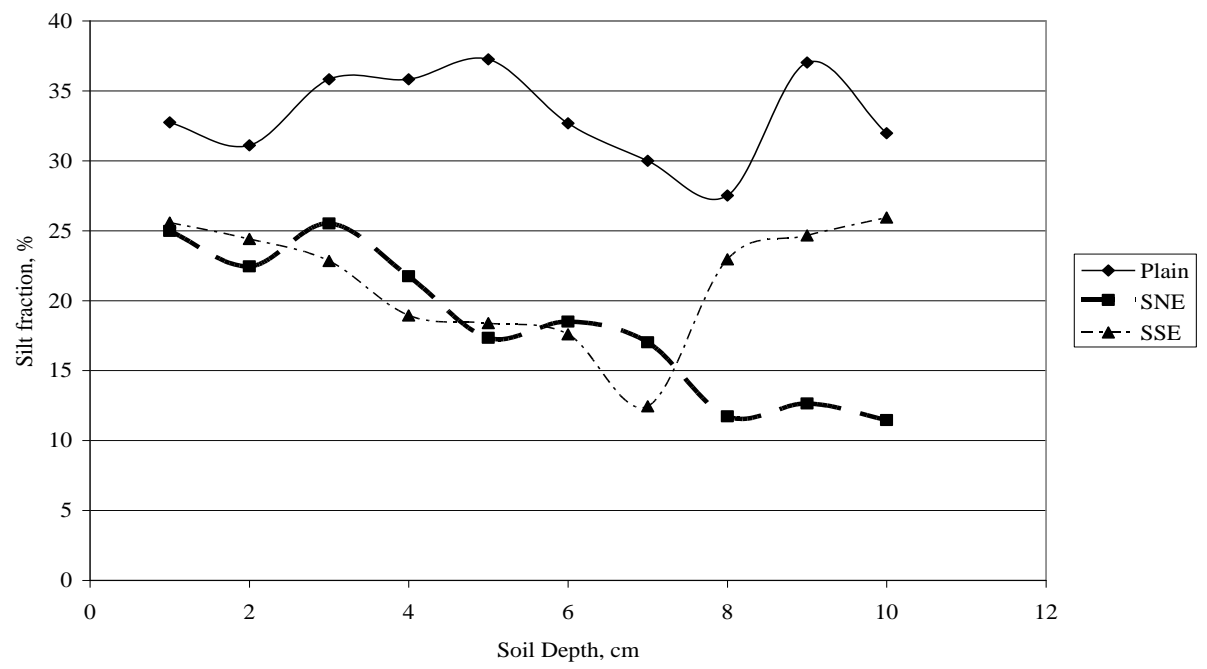

Fig.1. The silt fractions profile distribution in arable soils

The data obtained from the comparative analysis fixed changes in the content of soil particles depending on the environmental conditions. The texture of the arable soil in the plain is defined as silt-heavy loam. The content of fraction $<0.01 \mathrm{~mm}$ varies from 52,57 up to $53,96 \%$. The content of silt fraction $(<0.001 \mathrm{~mm})$ was $27,51-37,25 \%$. 
The silt content is reduced to $11,46-25,94 \%$ under the run-off impact in the first meter of soil on slopes. The eroded soil fertility is closely linked to the absorption capacity. It is known that the absorption capacity is directly dependent on the soil texture and the humus content. The absorption capacity data in the arable soils profile are given in the figure 2.

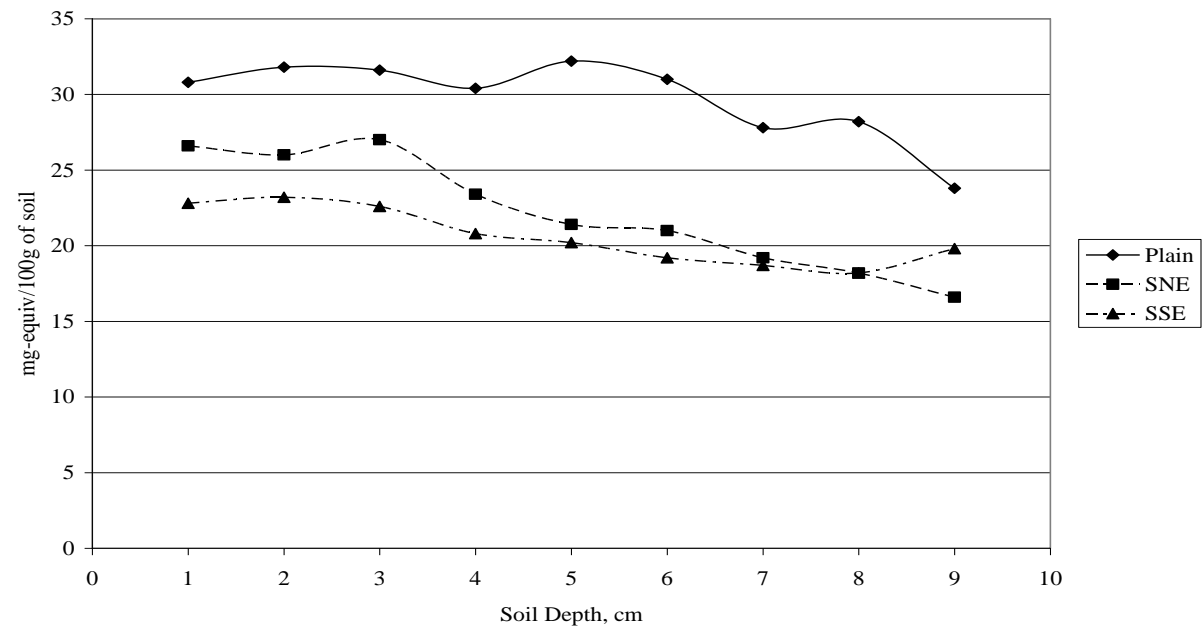

Fig.2. The absorption capacity distribution in soil profile of arable lands

The absorption capacity in the arable layer of $0-30 \mathrm{~cm}$ soil profile was at the level of $31.4 \mathrm{meq} / 100 \mathrm{~g}$ of soil. This index decreasing is $18 \%$ (on the northern slope) and $37 \%$ (on the slopes of the southern exposure) on eroded arable soils.

It was found that calcium has a large share in the amount of absorbed cations. The calcium content under the influence of runoff decreases with the depth. The maximum content of magnesium is observed in non-eroded black mollisols, especially at the depth of $40-80 \mathrm{~cm}$. The decrease of total amount of absorbed cations (ca+mg) along the soil profile is $42 \%$ (from 292 to $206 \mathrm{meq}$ $/ 100 \mathrm{~g}$ of soil). However, non-eroded soils have a high absorption capacity. It is explained by a significant amount of silt fraction.

Next data portion on carbonates distribution in the soil profile of arable lands is shown in the figure 3.the upper soil horizons washout and proximity to the land surface bottom leads to increase of carbonates content the soil surface. That is why the occurrence of carbonates on the slopes of the northern exposure is deeper than on the southern slopes. It was fixed the uptake of the carbonate horizon of medium and severely eroded soils to the surface. In other words, the deterioration of the soil material on these eroded soils dominates in comparison with the flow of the soil formation process. In accordance with data obtained, the content of carbonates in the $0-10 \mathrm{~cm}$ layer increased from $0.2 \%$ (plain) to $7.0 \%$ (the slope of the southern exposure), and in the layer of $0-30 \mathrm{~cm}$ from 1.4 to 8.8 $\%$, respectively. 


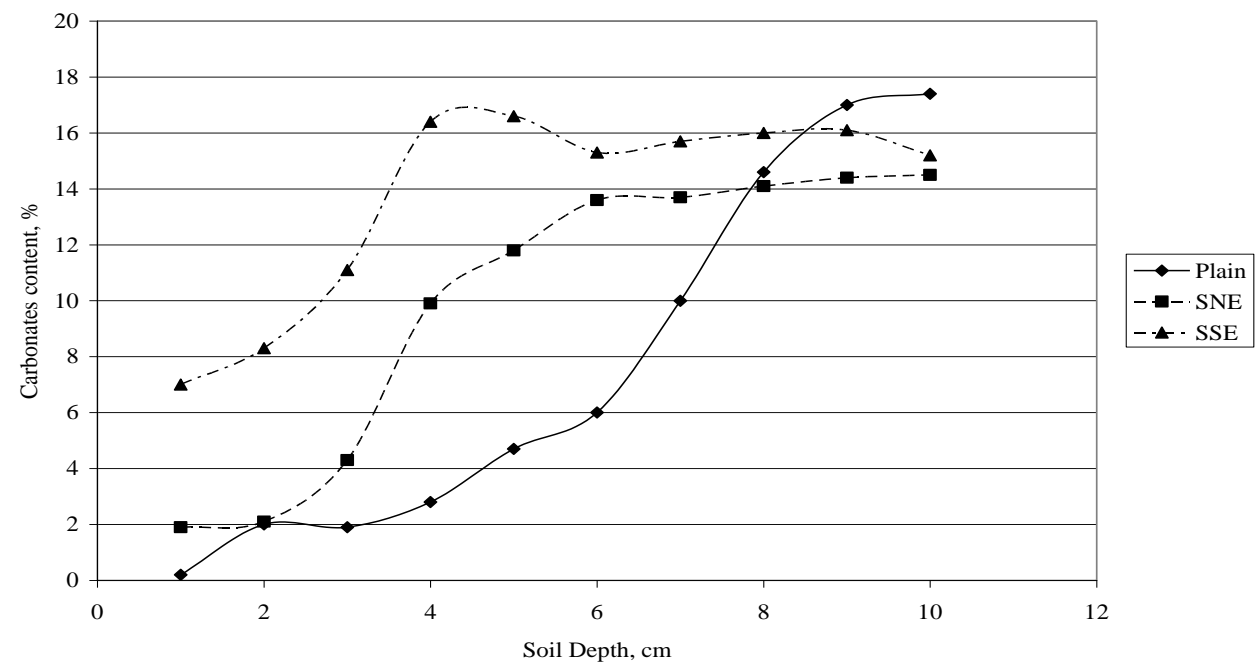

Fig.3. The carbonates distribution in soil profile of arable lands

It should be noted that the amount of carbonates in the layer of $0-10 \mathrm{~cm}$ of the northern exposure slope corresponds to the layer of 20-30 cm and the soil slope of the southern exposure of the $50-60 \mathrm{~cm}$ layer from the soil profile. These data confirm the regularity of carbonates displacement in the profile. There is a significant difference in their content in non-eroded and eroded to different degrees soils.

The distribution of carbonates in the soil profile allows to make a conclusion about the peculiarities of soils' wetting and the depth of moisture admission. According to calculations the stock of carbonates in the soil layer of one meter thick is washed away from $1262 \mathrm{t} /$ ha to $1715 \mathrm{t} / \mathrm{ha}$. It is $1.4-1.9$ times greater than in non-eroded black mollisols. Thus, the amount of carbonates increases significantly with increasing of erosion severity. This is one of the characteristic features of eroded soils of the steppe landscape. It is known that the soils' structure, their absorbed capacity, the nutrients mobility and the intensity of biological processes are closely related to the $\mathrm{pH}$ value. Erosion processes significantly affect the soil $\mathrm{pH}$ value. The $\mathrm{pH}$ value in the plain arable land in the layer of $0-20 \mathrm{~cm}$ thick equals 7.1. This value reaches up to 8,2-8,6 in eroded slope. Soil fertility is a multifactorial and dynamic phenomenon. The level and the ratio of the soil regime is also under the impact of erosion. The buffering capacity of the soil organic matter provides the basis of its fertility, as the most important evaluation criterion.

According to our research of E0 the humus content in the layer of $0-10 \mathrm{~cm}$ thick was $4.25 \%, 10-20 \mathrm{~cm}-4,05 \%, 20-30 \mathrm{~cm}$ and $3.9 \%$, declining at a depth of $70-80 \mathrm{~cm}$ to $1.4 \%$, and $90-100 \mathrm{~cm}$ to $0.6 \%$. At the time, as in E1 (the northern exposure slope) these indices were 3,$26 ; 2,9 ; 2,8 ; 0.7$ and $0.5 \%$; in E2 (the southern exposure slope ) $-2,0 ; 1,9 ; 1,8 ; 0.2$ and $0.1 \%$ respectively (Table $1)$. 
Table 1.The content and reserves of humus in arable lands.

\begin{tabular}{|c|c|c|c|c|c|c|c|c|c|}
\hline \multirow{2}{*}{$\begin{array}{c}\text { Soil } \\
\text { depth } \\
, \mathrm{cm}\end{array}$} & \multicolumn{3}{|c|}{ E0 } & \multicolumn{3}{|c|}{ E1 } & \multicolumn{3}{|c|}{ E2 } \\
\hline & $\%$ & $\mathrm{t} / \mathrm{ha}$ & C, $\%$ & $\%$ & $\mathrm{t} / \mathrm{ha}$ & C, $\%$ & $\%$ & $\mathrm{t} / \mathrm{ha}$ & C, $\%$ \\
\hline $0-10$ & 4.25 & 51.0 & 2.50 & 3.26 & 39.0 & 1.90 & 2.00 & 24.0 & 1.18 \\
\hline $10-20$ & 4.05 & 486 & 2.38 & 2.90 & 34.8 & 1.71 & 1.90 & 22.8 & 1.11 \\
\hline $20-30$ & 3.90 & 46.8 & 2.29 & 2.80 & 33.6 & 1.65 & 1.80 & 21.6 & 1.06 \\
\hline $30-40$ & 2.90 & 34.8 & 1.79 & 2.70 & 32.4 & 1.59 & 1.90 & 22.8 & 1.11 \\
\hline $40-50$ & 2.20 & 26.4 & 1.29 & 1.50 & 18.0 & 0.88 & 1.10 & 13.2 & 0.65 \\
\hline $50-60$ & 2.00 & 26.0 & 1.18 & 1.20 & 15.6 & 0.71 & 0.60 & 7.2 & 0.35 \\
\hline $60-70$ & 1.90 & 24.7 & 1.12 & 0.90 & 11.7 & 0.53 & 0.50 & 6.5 & 0.29 \\
\hline $70-80$ & 1.40 & 18.2 & 0.82 & 0.70 & 9.1 & 0.41 & 0.20 & 2.6 & 0.12 \\
\hline $80-90$ & 0.60 & 7.8 & 0.35 & 0.80 & 10.4 & 0.47 & 0.20 & 2.6 & 0.12 \\
\hline $\begin{array}{c}90- \\
100 \\
\end{array}$ & 0.60 & 7.8 & 0.35 & 0.50 & 6.5 & 0.29 & 0.10 & 1.3 & 0.06 \\
\hline $0-100$ & & 292,1 & & & 211,1 & & & 124,6 & \\
\hline
\end{tabular}

The reserves of humus in 0-100 cm layer decreased from 292,1 t/ ha (E0) to $211,1 \mathrm{t} /$ ha (E1) and 124,6 t/ ha (E2) accordingly because of the washout impact. A clear reduction of stocks of humus is observed in the topsoil (0-30 $\mathrm{cm}): 146,6 \mathrm{t} /$ ha to 107.4 and $68,4 \mathrm{t} / \mathrm{ha}$, representing $36 \%$ and 2.1 times.

Data on reduction of soil organic matter (SOM) content and reserves, reflect connection with the relief elements, and the difference in heat and solar radiation. The difference in heat and water regimes on the slopes of different exposure effect biomass production and microbial processes. The observed consequences are: different rates of accumulation, mineralization and humification of the SOM.

As a result of significant water erosion on the slopes of the southern exposure, the soils with lower humus content and humus shortened profile are formed. On the slopes of the northern exposure, where erosion processes are less spread, the depth of the humus profile and the humus content formation is greater than on the southern slopes by $40 \%$. However, in comparison with the plain soil, the humus content is reduced by $20 \%$ (the northern exposure slope) and 2 times (the southern exposure slope).

Analysis of the humus content of arable soils showed that the northern slope contains humus from 0.4 (90-100 cm layer) to $1.2 \%(0-10 \mathrm{~cm}$ layer) which is greater than the slope of the southern exposure, and $0.1-1 \%$ less than the plain black soil. Significant decrease of humus content (up to $2.0 \%$ ) is observed on the southern exposure slope. It can be explained not only by the water erosion impact, but also the soils water-physical properties.

As it is known, the loss of soil humus is under the influence of two processes: humus mineralization and erosion. However, the processes that lead to the soils dehumification on different elements of the landscape are different. Reducing the content of humus in soils in the watershed is solely due to the humus deterioration. But on the slopes it is due to the humus mineralization and 
erosion severity. Large humus losses in arable lands occur because of several reasons. Because of the nutrients uptake after harvesting, the arable soils current regime becomes insufficient to compensate the humus losses. Thus, a lower content of humus on arable slopes happens because of conditions for soils formation, the influence of erosion and cultivation technology. The extent of nutrients removal along with the plants biomass depend on the intensity and capacity of the biological cycle, the nature of active roots spread in the soil and detritus location.

The absolute content of humic acids depends on the amount of humus in the soil. So the content of humic acids in eroded soils is $0,670-0,775 \%$, fulvic acids $-0,348-0,360 \%$ and the ratio of $\mathrm{C}_{\mathrm{ha}}: \mathrm{C}_{\mathrm{fa}}$ is 1,82-of 2.23 (Table. 2).

Table 2. Humic and fulvic acids relation in arable soils.

\begin{tabular}{|c|c|c|c|c|c|}
\hline $\begin{array}{c}\text { Soil } \\
\text { profile }\end{array}$ & Depth, cm & Total C, \% & $\mathrm{C}_{\text {ha }}$ & $\mathrm{C}_{\mathrm{fa}}$ & $\underline{\underline{\mathrm{C}}_{\underline{h a}}}$ \\
\hline \multirow{2}{*}{ E0 } & $0-10$ & 2.50 & 0.775 & 0.348 & 2.23 \\
\cline { 2 - 6 } & $10-20$ & 2.38 & 0.670 & 0.369 & 1.82 \\
\hline \multirow{2}{*}{$\mathrm{E} 1$} & $0-10$ & 1.90 & 0.650 & 0.347 & 1.87 \\
\cline { 2 - 6 } & $10-20$ & 1.71 & 0.542 & 0.352 & 1.54 \\
\hline \multirow{2}{*}{ E2 } & $0-10$ & 1.18 & 0.370 & 0.350 & 1.06 \\
\cline { 2 - 6 } & $10-20$ & 1.11 & 0.360 & 0.350 & 1.03 \\
\hline
\end{tabular}

Different environmental conditions in the slopes of the northern and the southern exposures lead to a decrease in the humic acids quantity up to 0,650 $0,542 \%$ and $0,370-0,360 \%$. The content of fulvic acids is $0,347-0,352 \%$ and the ratio of $\mathrm{C}_{\mathrm{ha}}: \mathrm{C}_{\mathrm{fa}}$ decreases to $1.03-1,87$. The predominance of humic acids over fulvic acids is due to the activity of a large number of bacteria in the soil microflora. Thus, humic acids are one of the final products of plant residues transformation.

Organic matter (humus) is the main source of nitrogen. Plants that grow on the slopes are poorly spread, their leaves are of light green color. In other words, the nitrogen is a biogenic element whose presence in soil is associated with the processes of humus formation and biochemical activity.

\section{CONCLUSIONS}

The research of quantitative and qualitative composition of physical and chemical qualities in arable soils on the slopes and watersheds was performed. On the basis of it the dependence between the eroded soils fertility and environmental conditions was established. The slope soils are represented by the variety of watershed types of black mollisols. These soils are considered as special more arid soils additionally superimposed with erosion process. They represent genetic forms of intrazonal and zonal types.

The humus content in the $0-30 \mathrm{~cm}$ layer in the plain amounted to $4.1 \%$, while decreasing on the northern exposure slope by one third, and on the 
southern exposure slope - twice. The qualitative humus change was observed: the humic acid content decrease when insignificant change of fulvic acids. On the basis of the results obtained we conclude about a recognized need in application of biological conservation technologies for conditions of arid zones.

\section{ACKNOWLEDGEMENTS} Ukraine.

This work was supported with Ministry of Agrarian Policy and Food of

\section{REFERENCES}

Anisimova LB., Gritsan NP. Kharytonov MM. Land Distribution and Assessment in the Ukrainian Steppe within the Dnipropetrovsk Region. Regional Aspects of Climate Terrestrial - Hydrologic Interactions in Non-boreal Eastern Europe, Springer;2009. p.201-210

Artigas D An overview of South American Mollisols:Soil formation, classification, suitability and environmental challenges. In: Proceedings of the International Symposium on Soil Quality and Management of World Mollisols. Harbin:Northeast Forestry University Press; 2010. p.31-45;

Dokuchaev, VV Russian Chernozem. The report to the Imperator free economic society. SPtb Press, Russia;. $1883 . .482$ p. (in Russian)

Dokuchaev Soil Institute. Agrochemical methods of soil investigation. Ed. by USSR Academy of Science. Science Publishers, Moscow. 4th Ed. 1965. 436 p. (in Russian)

Kharytonov M, Bagorka M, Gibson P Erosion effects in the central steppe chernozem soils of Ukraine. I.Soil Properties. Agricultura. Published by the University of Maribor, Faculty of Agriculture, Slovenia; 2004; Vol.3. № 1:12-18.

Kovda VA. The problems of Earth biosphere and soil protection. Institute of Soil Science and Photosynthesis. Puschino, Russia; 1989. p.122-123 (in Russian)

Kharytonov MM, Mitsik OO, Pashova VT Development of Mathematic approaches to the Ecological Differentiation of Arable Land in the Dnipropetrovsk Area of Ukraine. Regional Aspects of Climate -Terrestrial -Hydrologic Interactions in Non-boreal Eastern Europe, Springer.2009.p.221-232

Kravchenko Y, Perenko L and Zhang, XY Ukrainian Chernozems: genesis, properties and amendment. 2010.p.3 - 24 in X. B. Liu, C. Y. Song, R. M. Cruse, and T.Huffman, eds. New advances in research and management of world Mollisols. Northeast Forestry University Press, Harbin,China

Kravchenko Y, Zhang X, Liu X et al. Mollisols properties and changes in Ukraine and China / Chinese Geographical Science;2011; Vol. 21: 257-266

Liu X et al. Overview of Mollisols in the world: Distribution, land use and management. Can. J. Soil Sci. 2012; 92: 383-402

Kravchenko Y Rogovska, N, Petrenko L, Zhang X, Song C and Chen Y "Quality and dynamics of soil organic matter in a typical Chernozem of Ukraine under different long-term tillage systems”. In: Can. J. Soil Sci. 2012;. 92: 429-438

Liu X et al. Overview of Mollisols in the world: Distribution, land use and management. Can. J. Soil Sci. 2012; 92: 383-402.

Spalevic V, Curovic M, Borota D, Fustic, B. (2012): Soil erosion in the River Basin Zeljeznica, area of Bar, Montenegro. Agriculture and Forestry, 54 (1-4): 5-24

Spalevic, V., Curovic, M., Barovic, G., Vujacic, D., Tunguz, V. and Djurovic, N. (2015): Soil erosion in the river basin of Provala, Montenegro. Agriculture and Forestry, 61(4): 133-143 